\title{
Oxygen consumption in relation to motion of marine planktonic copepods
}

\author{
Gustav-Adolf Paffenhöfer* \\ Skidaway Institute of Oceanography, 10 Ocean Science Circle, Savannah, Georgia 31411, USA
}

\begin{abstract}
The goal of these studies was to quantify the energy consumption of abundant marine planktonic copepods with different motion behaviors but similar body weight by determining their oxygen consumption under conditions approaching those encountered in their natural environment. The motion behaviors of adult females of the 3 copepod taxa studied ranged from the continuously fast-moving Clausocalanus furcatus to the continuously slow-moving and feeding current-producing Paracalanus aculeatus to the occasionally moving Oncaea spp. At $20^{\circ} \mathrm{C}$, the daily oxygen consumption per unit body weight decreased significantly with decreasing activity, i.e. C. furcatus $>$ P. aculeatus > Oncaea spp. Expressed as percent of body carbon metabolized per day, the average values were $23.4 \%$ for $C$. furcatus, $15.1 \%$ for $P$. aculeatus, and $10.5 \%$ for Oncaea spp. Oxygen consumption of $P$. aculeatus and Oncaea spp. was significantly higher at $23^{\circ} \mathrm{C}$ than at $20^{\circ} \mathrm{C}$. It is concluded that not only body weight and temperature, but also the extent of motion will affect energy expenditures of planktonic copepods.
\end{abstract}

KEY WORDS: Oxygen · Motion · Copepods

Resale or republication not permitted without written consent of the publisher

\section{INTRODUCTION}

The activities of marine planktonic copepods range from occasional motion to continuous rapid swimming (e.g. Gauld 1966, Paffenhöfer et al. 1996, Mazzocchi \& Paffenhöfer 1999). According to modeling studies, increased motion results in increased metabolic expenditures (e.g. Klyashtorin \& Yarzombek 1973). To date, oxygen consumption of copepods has been related to body mass and temperature (e.g. Ikeda 1985, Hiromi et al. 1988, Castellani et al. 2005), to general feeding behavior (Klekowski et al. 1977), and to diel cycles (Pavlova 1994). In the subtropical to tropical open ocean, abundances of potential food organisms for planktonic copepods are usually low compared to neritic regions (Paffenhöfer et al. 2003), which implies that metabolic and growth demands may not always be met (e.g. Dam et al. 1995, Roman \& Gauzens 1996). The goal of this study was to quantify the oxygen consumption of 3 taxa of abundant subtropical/tropical planktonic copepods with different motion behaviors, and determine to what extent 2 of the 3 were able to meet their metabolic needs at environmental food concentrations found at 3 different locations of the subtropical to tropical western Atlantic Ocean.

\section{MATERIALS AND METHODS}

The copepods in the present study were adult females of the calanoids Clausocalanus furcatus and Paracalanus aculeatus, and the poecilostomatoid Oncaea spp. C. furcatus and P. aculeatus occur abundantly from the middle southeastern continental shelf to the open ocean off the USA (Bowman 1971) and in the tropical Caribbean (Webber \& Roff 1995), as does the genus Oncaea (Paffenhöfer et al. 1984, Webber \& Roff 1995). C. furcatus and Oncaea spp. were collected on the middle and outer shelf (30 to $50 \mathrm{~m}$ isobath) off the southeastern USA at surface temperatures ranging from about 18 to $24^{\circ} \mathrm{C}$, using oblique tows from near the sea floor to the surface with openmouth nets of $200 \mu \mathrm{m}$ mesh equipped with codends of 41 capacity. They were immediately placed in 21 glass 
jars filled with unfiltered seawater collected with Niskin bottles at mid-depth at the same location, and kept at temperatures near 20 to $23^{\circ} \mathrm{C}$ until arrival at the laboratory. There they were transferred into jars of unfiltered seawater collected at the location of copepod collection. The dinoflagellate Gymnodinium nelsoni was added at a concentration of about $15 \mu \mathrm{gC} \mathrm{l}^{-1}$ to the $C$. furcatus jars, and at about $65 \mu \mathrm{gC} \mathrm{l}^{-1}$ to the Oncaea jars, each of which had a capacity of 1900 to $3800 \mathrm{ml}$. These jars were mounted on a plankton wheel which rotated at about $0.3 \mathrm{rpm}$. Maintenance temperature was 20 to $21^{\circ} \mathrm{C}$ with a $12: 12 \mathrm{~h}$ light:dark cycle. These females were used for experiments within 1 to $3 \mathrm{~d}$ of collection. The $P$. aculeatus females had been reared in the laboratory at $20^{\circ} \mathrm{C}$ on a plankton wheel, feeding on the flagellates Isochrysis galbana $(4.5 \mu \mathrm{m}$ equivalent spherical diameter, ESD) and Rhodomonas sp. (8.2 $\mu \mathrm{m}$ ESD), each at approximate average concentrations of 15 to $30 \mu \mathrm{gC} \mathrm{l}^{-1}$. They originated from females collected on the outer shelf using the methods described above. As the copepodids approached copepodid stage $\mathrm{V}$, they received only Rhodomonas sp. at near 10 to $15 \mathrm{\mu gC}^{-1}$ average food concentration in order to acclimate them to food levels close to those found in the upper $75 \mathrm{~m}$ of the open subtropical ocean (Paffenhöfer et al. 2003). Only fertilized females that had molted to adult less than $10 \mathrm{~d}$ prior to an experiment were used.

Oxygen consumption was quantified in Plexiglas chambers of 230 to $460 \mathrm{ml}$ capacity, rotating at about $0.3 \mathrm{rpm}$ on a plankton wheel, using the microWinkler method (Jahnke \& Craven 1994). Each chamber had 2 narrow stoppered openings allowing simultaneous withdrawal and addition of seawater. Experiments were run at 20 and $23^{\circ} \mathrm{C}$ over periods of 20 to $24 \mathrm{~h}$. The larger chambers $(460 \mathrm{ml})$ were always used for Clausocalanus furcatus, which moved at velocities of up to $10 \mathrm{~mm} \mathrm{~s}^{-1}$, in order to limit wall encounters, and also for some experiments with Paracalanus aculeatus. The smaller chambers $(230 \mathrm{ml})$ were used for Oncaea spp., which only moved occasionally, and for $P$. aculeatus, which moved at velocities of about $0.4 \mathrm{~mm} \mathrm{~s}^{-1}$ while creating a feeding current, and were not affected in their feeding activities when they occasionally encountered walls. Copepod concentrations in the experimental chambers ranged from 12 to 25 per $100 \mathrm{ml}$ for C. furcatus, from 20 to 40 per $100 \mathrm{ml}$ for Oncaea spp., and from 17 to 35 per $100 \mathrm{ml}$ for $P$. aculeatus. One to 3 control chambers were run simultaneously. Oxygen concentrations in the experimental chambers at the end of experiments were never below $70 \%$ of the initial concentration. To provide food during the experimental periods, Gymnodinium nelsoni was added at about $15 \mu \mathrm{gC}^{-1}$ to the jars containing Oncaea spp. and C. furcatus, and Rhodomonas sp. at $15 \mu \mathrm{gC}^{-1}$ to those containing $P$. aculeatus.
At the beginning and end of each experiment, each of the chambers was slowly turned top over bottom to achieve gentle mixing prior to drawing $10.0 \mathrm{ml}$ with a glass syringe. At the same time, $10.0 \mathrm{ml}$ of filtered seawater, identical with that in the chambers, was sucked into the respective chamber from an identical glass syringe. This method ascertained that the water in the control and experimental chambers had no intermittent contact with air prior to being analyzed. Replicate $4.0 \mathrm{ml}$ samples were taken from this $10 \mathrm{ml}$ and used to determine oxygen content using a micro-burette with an accuracy of $\pm 1 \mu$ of sodiumthiosulfate, which was repeatedly calibrated (Jahnke \& Craven 1994). The oxygen consumption data and copepod body weights were converted into units of calories (1 $\mathrm{ml}$ oxygen respired equaled $4.86 \mathrm{cal}$ at a respiratory quotient of $1.0 ; 1 \mathrm{mg}$ ash-free dry weight equaled $5.0 \mathrm{cal}$, Winberg 1971, Omori \& Ikeda 1984). Ikeda (1985) developed regressions relating oxygen uptake of zooplankton to their body weight. To compare his results with those of this study his equation will be applied:

$$
\ln y=a_{0}+a_{1} \ln X_{1}+a_{2} X_{2}
$$

where $y$ is oxygen respired $\left(\mu l\right.$ ind.$\left.^{-1} \mathrm{~h}^{-1}\right) ; X_{1}$ is the body mass of an individual (mg dry weight); $X_{2}$ is temperature; and $a_{0}, a_{1}$ and $a_{2}$ are constants.

To obtain ingestion rates of Paracalanus aculeatus females at near oligotrophic conditions, laboratory feeding experiments were conducted with just fertilized females which had been reared on several species of phytoplankton at levels close to oligotrophic conditions. At $20^{\circ} \mathrm{C}, 4$ different phytoplankton species, including Isochrysis galbana (4.5 $\mu \mathrm{m}$ ESD), Rhodomonas sp. (8.2 $\mu \mathrm{m}$ ESD), Thalassiosira weissflogii (11.5 $\mu \mathrm{m}$ ESD) and T. eccentrica (32 $\mu \mathrm{m}$ ESD), were offered alone or in pairs at total concentrations ranging from 5 to $15 \mathrm{\mu gC} \mathrm{l}^{-1}$, i.e. close to those found in the subtropical to tropical Atlantic in the nanoplankton range (Paffenhöfer et al. 2003). Methodology included a 12:12 h light:dark cycle, $960 \mathrm{ml}$ glass jars, $0.3 \mathrm{rpm}$ on plankton wheels, 18 to $22 \mathrm{~h}$ experimental periods, and particle quantification using an inverted microscope and a Coulter Multisizer with a $140 \mu \mathrm{m}$ diameter orifice tube. These experiments were used to calculate the clearance rates (Frost 1972) to be applied to natural food abundances (Paffenhöfer et al. 2003) in order to determine their food intake (Table 1). Clearance rates for Clausocalanus furcatus originated from in situ studies in the subtropical open ocean (Table 1, Paffenhöfer et al. 2006).

Statistical tests included the Kruskal-Wallis nonparametric analysis of variance by ranks, which was followed by a multiple comparison test if the null hypothesis was not rejected (Conover 1980). 
Table 1. Paracalanus aculeatus and Clausocalanus furcatus. Clearance rates $\left(\mathrm{ml}\right.$ ind. ${ }^{-1} \mathrm{~d}^{-1}$ ) of $P$. aculeatus females at $20^{\circ} \mathrm{C}$ at various particle size ranges feeding on different phytoplankton species at total concentrations ranging from 5 to $15 \mu \mathrm{gC} \mathrm{l}^{-1}$ and comparative data for $C$. furcatus females at $23^{\circ} \mathrm{C}$, feeding on in situ particles (Paffenhöfer et al. 2006). ESD: equivalent spherical diameter

\begin{tabular}{|lcc|}
\hline $\begin{array}{l}\text { Size range } \\
(\mu \mathrm{m}, \mathrm{ESD})\end{array}$ & P. aculeatus & C. furcatus \\
\hline $2-4$ & - & \\
$4-6$ & 31 & 28 \\
$6-8$ & 58 & 40 \\
$8-10$ & 106 & 55 \\
$10-20$ & 195 & 78 \\
$20-40$ & 320 & 237 \\
\hline
\end{tabular}

\section{RESULTS}

Mortality during the oxygen consumption experiments was zero for Paracalanus aculeatus, less than $2 \%$ for Oncaea spp., and between 0 and $5 \%$ for Clausocalanus furcatus. At the end of each experiment, most $C$. furcatus females were moving slower than at the beginning, indicating that the encroaching conditions or food limitation affected their motion. However, within several hours after being returned to a $3800 \mathrm{ml}$ jar on the plankton wheel containing Gymnodinium nelsoni at concentrations of $\sim 10 \mu \mathrm{gC}^{-1}, C$. furcatus had regained most of their initial motion activity. Also, $P$. aculeatus and Oncaea spp. escaped less effectively at the end than at the beginning of an experiment. Oncaea spp. and C. furcatus consumed all food particles in their chambers, while food concentrations in the $P$. aculeatus chambers diminished to close to $1 \mu \mathrm{gC} \mathrm{l}^{-1}$.

The individual data indicate that Oncaea spp. had the lowest, and Clausocalanus furcatus the highest, oxygen consumption rate in relation to their ash-free dry weight at both 20 (Fig. 1) and $23^{\circ} \mathrm{C}$ (Table 2). Oncaea spp. were the lightest and Paracalanus aculeatus the heaviest (Fig. 1, Table 2). The results reveal that on average Oncaea spp. consumed $4.74 \mu$ l oxygen $\mathrm{mg}^{-1} \mathrm{~h}^{-1}, P$. aculeatus $6.56 \mu \mathrm{mg}^{-1} \mathrm{~h}^{-1}$, and C. furcatus $11.32 \mu \mathrm{mg}^{-1} \mathrm{~h}^{-1}$ at $20^{\circ} \mathrm{C}$ (Table 2). These data were significantly different from each other $(p<0.05$, Kruskal-Wallis test with ensuing multiple comparison test, Conover 1980). The respective average values at $23^{\circ} \mathrm{C}$ were 6.52, 9.63 and $13.81 \mu \mathrm{mg}^{-1} \mathrm{~h}^{-1}$ (Table 2). For Oncaea spp. and P. aculeatus, the values measured at $20^{\circ} \mathrm{C}$ were significantly lower than those at $23^{\circ} \mathrm{C}(\mathrm{p}<$ 0.05 , Kruskal-Wallis test). At $20^{\circ} \mathrm{C}$, the occasionally moving Oncaea spp. females (inactive $74.4 \%$ of the time, Paffenhöfer et al. 2006) metabolized on average $10.5 \%$ of their body weight per day, the continuously but slowly moving and feeding current-creating $P$. aculeatus females (0.33 $\mathrm{mm} \mathrm{s}^{-1}$, Paffenhöfer et al. 1996)

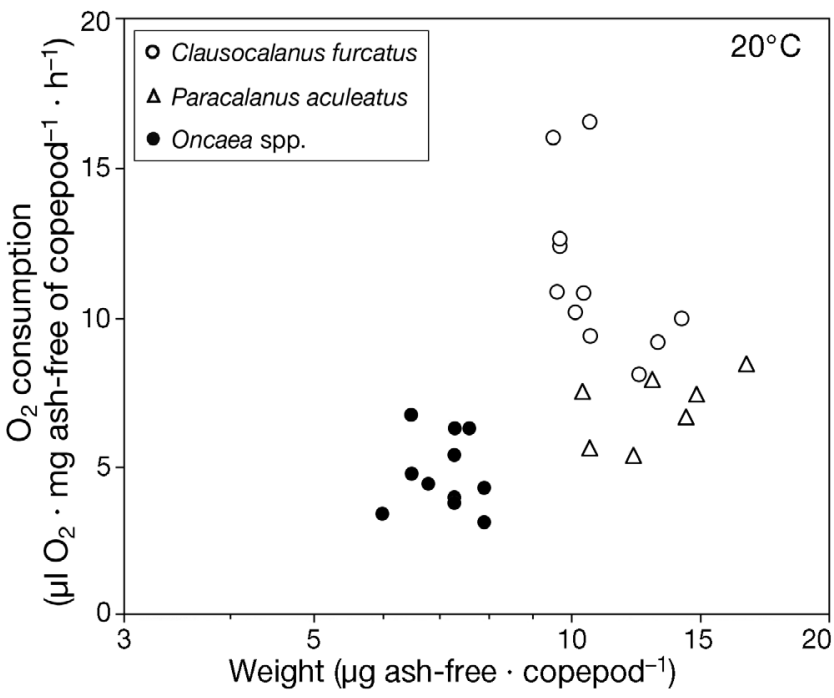

Fig. 1. Oncaea spp., Paracalanus aculeatus and Clausocalanus furcatus. Oxygen consumption of females in relation to their body weight at $20^{\circ} \mathrm{C}$

metabolized $15.1 \%$, and the continuously fast-moving C. furcatus females (6 to $10 \mathrm{~mm} \mathrm{~s}^{-1}$, Mazzocchi \& Paffenhöfer 1999) metabolized $23.4 \%$. At $23^{\circ} \mathrm{C}$, the respective data were $15.2,22.4$, and $32.2 \%$.

\section{DISCUSSION}

\section{Oxygen consumption and copepod motion}

To date, no empirical data are available directly comparing oxygen consumption or metabolic expenditures of planktonic copepods with their motion. So far, evaluations of metabolic expenditures in relation to motion have been based on fluid dynamics theory. The

Table 2. Oxygen consumption of marine planktonic copepods $\left(\mu \mathrm{l} \mathrm{mg}^{-1}\right.$ ash-free dry weight $\mathrm{h}^{-1}$ ), average ash-free dry weight, and number of observations $( \pm 1 \mathrm{SE})$

\begin{tabular}{|lccc|}
\hline Species & $\begin{array}{c}\text { Ash-free } \\
\text { dry weight }(\mu \mathrm{g})\end{array}$ & $\mathrm{n}$ & $\begin{array}{c}\text { Oxygen } \\
\mu \mathrm{O} \mathrm{O}_{2} \mathrm{mg}^{-1} \mathrm{~h}^{-1}\end{array}$ \\
\hline $\begin{array}{l}\mathbf{2 0}{ }^{\circ} \mathbf{C} \\
\text { Clausocalanus } \\
\text { furcatus }\end{array}$ & $10.7 \pm 0.47$ & 11 & $11.32 \pm 0.84$ \\
$\begin{array}{c}\text { Paracalanus } \\
\text { aculeatus }\end{array}$ & $12.6 \pm 0.67$ & 8 & $6.56 \pm 0.53$ \\
$\begin{array}{l}\text { Oncaea spp. } \\
\mathbf{2 3}{ }^{\circ} \mathbf{C}\end{array}$ & $7.1 \pm 0.18$ & 11 & $4.74 \pm 0.37$ \\
$\begin{array}{c}\text { Clausocalanus } \\
\text { furcatus }\end{array}$ & $9.6 \pm 0.32$ & 5 & $13.81 \pm 1.36$ \\
$\begin{array}{c}\text { Paracalanus } \\
\text { aculeatus }\end{array}$ & $12.5 \pm 1.08$ & 8 & $9.63 \pm 0.80$ \\
Oncaea spp. & $7.4 \pm 0.17$ & 11 & $6.52 \pm 0.62$ \\
\hline
\end{tabular}


most advanced modeling effort for copepod swimming expenditures was made by Morris et al. (1985). They included variables such as mechanical energy required for appendage movement, kinetic energy dissipation in the fluid, and metabolic costs of swimming in their assessment. Their model is in agreement with empirical observations of larger crustaceans (e.g. shrimps), which indicate that swimming should be energetically expensive. This disagrees with earlier calculations using fewer variables, which concluded that copepod swimming would require little energy (e.g. Klyashtorin \& Yarzombek 1973).

Quantifications of oxygen consumption by nauplii and copepodid stages of the cyclopoid Mesocyclops brasilianus revealed major differences between nauplii and post-nauplii (Epp \& Lewis 1979). Specifically, while nauplius stage VI (NVI, $0.22 \mu \mathrm{g}$ dry weight), which rarely moves, respired $13.9 \times 10^{-4} \mathrm{\mu l}$ oxygen $\mathrm{h}^{-1}$ at $24^{\circ} \mathrm{C}$, copepodid stage I (CI, $0.23 \mu \mathrm{g}$ dry weight), which moves frequently, respired $34.4 \times 10^{-4} \mu$ l oxygen $\mathrm{h}^{-1}$. While the body mass had hardly changed, the motion had increased sharply, and with it oxygen consumption by a factor of about 2.5 . Which variables could be responsible for such differences in oxygen consumption? The mechanical energy costs of appendage movement and the metabolic costs of swimming described by Morris et al. (1985) may play a role. While a nauplius has 3 pairs of appendages, a CI has 6 pairs of cephalic appendages and 2 pairs of swimming feet. Thus, not only the energy for body propulsion but also that for motion of the different number and morphologies of appendages should contribute to the overall energy costs.

Concerning the 3 copepod taxa studied here, Paracalanus aculeatus late copepodids and females move continuously at $0.33 \mathrm{~mm} \mathrm{~s}^{-1}$, creating a feeding current at a mouthpart frequency of $80 \mathrm{~Hz}$ (Paffenhöfer et al. 1996). The similarly sized Clausocalanus furcatus females also move continuously, but at 6 to $10 \mathrm{~mm} \mathrm{~s}^{-1}$; the mouthpart frequency is unknown (Mazzocchi \& Paffenhöfer 1999). Oncaea spp. females are motionless/sinking for $74.4 \pm 8.3 \%$ (SE) of the time during light hours at $20^{\circ} \mathrm{C}$ (Paffenhöfer et al. 2006). Morris et al. (1985) calculated that at a swimming speed of 5.2 body lengths $\mathrm{s}^{-1}$ the metabolism of the copepod Pleuromamma xiphias $(6 \mathrm{~mm}$ prosome length) was 3.1. times higher that its standard (non-moving) metabolism. If one takes the weight-specific energy expenditure of a female Oithona similis at $20^{\circ} \mathrm{C}(10.5 \%$, Castellani et al. 2005 , Table 3), being slightly smaller than $C$. furcatus, as an approximate non-moving metabolic expenditure, the metabolism of $C$. furcatus $(23.4 \%)$ moving at 6 to 10 body lengths $\mathrm{s}^{-1}$, i.e. about 2.2 times that of a rarely moving copepod, would be in the range of that of the moving $P$. xiphias.

\section{Oxygen consumption of small copepods}

Oxygen consumption rates of small planktonic copepods were normalized to daily metabolic expenditures as percent of their body weight, applying conversion factors of Omori \& Ikeda (1984, shown in 'Materials and methods'). These rates had been obtained at different temporal and spatial conditions, ranging from microrespirometers where a copepod was placed in less than $1 \mathrm{ml}$ (Klekowski 1977), through vessels of 60 ml capacity (Nakamura \& Turner 1997, Castellani et al. 2005), to this study's 230 and $460 \mathrm{ml}$ chambers. The daily metabolic expenditures measured by the different authors for each of the genera Oithona and Oncaea varied by a factor of about 2 (Table 3 ). Since Oithona and Oncaea only move occasionally, one could expect similar expenditures for both, as was found in the most recent quantifications (Castellani et al. 2005 and this study). The variability of rates observed for each of the 2 genera (Table 3 ) is most likely due to differing methodology, including vessel volume, pre-experimental treatment, geographical location, different behavior among species within a genus, and the age of the experimental adult females. Even though identical methods were applied, the individual data of this study (Fig. 1) show an approximately 2-fold difference between the lowest and highest values for each of the

Table 3. Daily metabolic expenditures calculated from oxygen consumption quantifications, expressed as \% of each copepod's body weight

\begin{tabular}{|lccc|}
\hline $\begin{array}{l}\text { Genus/ } \\
\text { Species }\end{array}$ & $\begin{array}{c}\text { Temperature } \\
\left({ }^{\circ} \mathrm{C}\right)\end{array}$ & $\begin{array}{c}\text { Daily metabolic } \\
\text { expenditures } \\
\text { (\% of body weight) }\end{array}$ & Source \\
\hline Oncaea & 20 & 55 & Klekowski et al. (1977) \\
Calocalanus & 20 & 10.7 & \\
Oithona & 20 & 19.1 & \\
Paracalanus & 20 & 24.7 & Gaudy \& Boucher (1983) \\
Clausocalanus & 20 & 28.0 & Hiromi et al. (1988) \\
Oncaea venusta & 20 & 9.8 & Castellani et al. (2005) \\
Oithona davisae & 20 & 20.9 & \\
Oithona similis & 19 & 20.3 & \\
Oithona similis & 20 & 10.5 & \\
Oncaea spp. & 20 & 10.5 & \\
Paracalanus & & 15.1 & \\
aculeatus & 20 & 23.4 & \\
Clausocalanus & & & \\
furcatus & 20 & &
\end{tabular}


3 copepods. In essence, a general comparison of all data in Table 3 reveals that the rarely moving copepods had the lowest metabolic rates and the fastest moving ones had the highest.

Applying Ikeda's (1985) equation for oxygen uptake in relation to a temperature of $20^{\circ} \mathrm{C}$ and a body mass of $10 \mu \mathrm{g}(0.010 \mathrm{mg})$ dry weight, such a small copepod would metabolize $12.8 \%$ of its body weight daily. Such a value would be relatively close to those obtained for Oncaea spp. and Paracalanus aculeatus in our experiments, but far lower than the results for Clausocalanus furcatus. Although a generalization like Ikeda's (1985) reveals overall relationships between temperature, body mass and metabolic rates, quantifications of individual rates in relation to a species' behavior are needed as they reveal part of that organism's means to operate and exist.

A comparison between our respiration rates at 20 and $23^{\circ} \mathrm{C}$ indicated metabolic increases of $22.0 \%$ for Clausocalanus furcatus, $46.8 \%$ for Paracalanus aculeatus, and $37.6 \%$ for Oncaea spp. (Table 2). What could such different increases imply? Again applying Ikeda's (1985) regression for oxygen consumption, an increase from 20 to $23^{\circ} \mathrm{C}$ for a small copepod of $4 \mu \mathrm{g}$ carbon (10 $\mu \mathrm{g}$ ash-free dry weight) should result in an increase in oxygen consumption of $19.8 \%$. This would imply that $C$. furcatus would be less affected metabolically by such a temperature increase than the other 2 copepods. This could partly explain why this species has been found regularly near temperatures of $25^{\circ} \mathrm{C}$ and even above in the warm open ocean, in contrast to the genus Oncaea, which usually increases in abundance with depth and decreasing temperatures below $40 \mathrm{~m}$, and reaches highest concentrations near $100 \mathrm{~m}$ depth (Paffenhöfer \& Mazzocchi 2003).

\section{Ingestion rates and metabolic needs}

Are previously quantified ingestion rates (Paffenhöfer et al. 2006) sufficient to support the metabolic expenditures presented in this study? Using particle concentrations $\left(\mathrm{\mu gC} \mathrm{l}^{-1}\right)$ quantified for the range from 2 to $40 \mu \mathrm{m}$ ESD at 3 different stations at 2 different depths in the western tropical and subtropical Atlantic Ocean (Paffenhöfer et al. 2003) where Clausocalanus spp. is dominant and Paracalanus aculeatus common to abundant (Webber \& Roff 1995), ingestion rates were calculated for females of both species by applying previously quantified clearance rates for the different particle size ranges for $C$. furcatus (Paffenhöfer et al. 2006), and clearance rates from experiments described earlier for $P$. aculeatus (Table 1). The ingestion rates of particles in the abovementioned range are thought to be a function of their volume (Bartram 1981, Paffenhöfer et al. 2006). Applying an assimilation effi- ciency of $90 \%$ (Conover 1979, Paffenhöfer \& Köster $2005)$ and the abovementioned daily metabolic expenditures in \% of body carbon at $23^{\circ} \mathrm{C}(32.2 \%$ for C. furcatus, and $22.4 \%$ for $P$. aculeatus), ingestion rates of $C$. furcatus and $P$. aculeatus met metabolic needs in 3 and 4 out of 6 cases, respectively (Table 4 ). In the case of $P$. aculeatus, part of the ingested food would be available for reproduction. At Stns 19 and 35, the food concentrations appeared to be quite sufficient to support the metabolic needs of both copepods, while at Stn 11a at both depths, neither copepod could obtain sufficient amounts of food. As abundance of these copepods is continually very low in oligotrophic waters (e.g. Webber \& Roff 1995) and ingestion rates of adult females barely meet or exceed metabolic needs, one could speculate that reproduction rates at in situ food abundances are severely limited. No meaningful calculations could be made for Oncaea spp. for which credible ingestion rates for the subtropical/tropical open ocean are not yet available.

Almost all previously obtained oxygen consumption measurements of planktonic copepods were made without offering food to the experimental animals. Thus, these quantifications should not be identical with rates in their natural environment, as the results from Kiørboe et al. (1985) for an estuarine copepod indicate. They found an increase in oxygen consumption rates with increasing food concentrations. The experiments in this paper used food abundances resembling the regularly found low environmental abundances at the beginning of each period as an attempt to simulate the natural environment of the copepods. Furthermore, the limited space in experiments could have an effect on oxygen consumption. It

Table 4. Clausocalanus furcatus and Paracalanus aculeatus. Ingestion rates (ng C female ${ }^{-1} \mathrm{~d}^{-1}$ ) at $23^{\circ} \mathrm{C}$ at environmental concentrations of combined phyto- and protozooplankton from 2 to $40 \mu \mathrm{m}$ ESD from 3 different stations in the western Atlantic (Paffenhöfer et al. 2003), and daily assimilation as percentage of body C (at $90 \%$ assimilation efficiency). Clearance rates of $P$. aculeatus obtained at $20^{\circ} \mathrm{C}$ were assumed to be similar to those at $23^{\circ} \mathrm{C}$. Ingestion rates of $C$. furcatus from Paffenhöfer et al. (2006). *: copepods met metabolic requirements

\begin{tabular}{|lrrrr|}
\hline Stn & $\begin{array}{c}15 \mathrm{~m} \\
\text { Ingestion }\end{array}$ & Assimilation & $\begin{array}{c}4 \\
\text { Ingestion }\end{array}$ & Assimilation \\
\hline C. furcatus & & & & \\
$11 \mathrm{a}$ & 680 & 20.8 & 784 & 23.8 \\
19 & 1102 & $36.3^{*}$ & 1187 & $39.0^{*}$ \\
35 & 1299 & $42.6^{*}$ & 972 & 31.9 \\
$\boldsymbol{P .}$ aculeatus & & & & \\
$11 \mathrm{a}$ & 829 & $16.6^{*}$ & 1045 & 20.7 \\
19 & 1446 & $28.6^{*}$ & 1695 & $33.5^{*}$ \\
35 & 1809 & $35.7^{*}$ & 1329 & $26.3^{*}$ \\
\hline
\end{tabular}


was attempted to improve on this in the present study by utilizing larger vessel volumes. Yet, the concentrations of copepods required to obtain significant oxygen reductions are such that vessels with volumes large enough to have little effect on copepod motion (>2000 ml, judging from their motion) would require extraordinary abundances of copepods. This means that the methods applied so far ought to be improved upon.

In conclusion, the data from this study reveal more than 2-fold differences in oxygen consumption between planktonic copepods with different motion behaviors. Such energy consumption could be roughly seen as a function of the motion activity of the respective taxon. These results may also give rise to thoughts about the means of operation of the different taxa, which allow them to persist in a narrower or wider range of environments, ranging from the coastal to the oligotrophic open ocean.

Acknowledgements. This research was supported by a grant from the National Science Foundation (OCE 99 11513). R. and D. Jahnke provided equipment and valuable advice for the microWinkler quantifications. J. Williams skillfully built the oxygen consumption chambers. The captain and crew of the RVs 'Blue Fin' and 'Savannah' cooperated dependably and competently. Their support is gratefully acknowledged.

\section{LITERATURE CITED}

Bartram WC (1981) Experimental development of a model for the feeding of neritic copepods on phytoplankton. J Plankton Res 3:25-51

Bowman TE (1971) The distribution of calanoid copepods off the southeastern United States between Cape Hatteras and southern Florida. Smithson Contrib Zool No. 96

Castellani C, Robinson C, Smith T, Lampitt RS (2005) Temperature affects respiration rate of Oithona similis. Mar Ecol Prog Ser 285:129-135

Conover RJ (1979) Secondary production as an ecological phenomenon. In: van der Spoel S, Pierre-Bults AC (eds) Zoogeography and diversity of plankton. Bunge Scientific Publishers, Utrecht, p 50-86

Conover WJ (1980) Practical nonparametric statistics. John Wiley \& Sons, New York

Dam HG, Zhang X, Butler M, Roman MR (1995) Mesozooplankton grazing and metabolism at the equator in the central Pacific: Implication for carbon and nitrogen fluxes. Deep-Sea Res II 42:735-756

Epp RW, Lewis WM Jr (1979) Metabolic responses to temperature change in a tropical freshwater copepod (Mesocyclops brasilianus) and their adaptive significance. Oecologia 42:123-138

Frost BW (1972) Effects of size and concentration of food particles on the feeding behavior of the marine planktonic copepod Calanus pacificus. Limnol Oceanogr 17:805-815

Gaudy R, Boucher J (1983) Relation between respiration, excretion (ammonia and inorganic phosphorus) and activity of amylase and trypsin in different species of pelagic copepods from an Indian Ocean equatorial area. Mar Biol $75: 37-45$
Gauld DT (1966) The swimming and feeding of planktonic copepods. In: Barnes H (ed) Some contemporary studies in marine science. Allen \& Unwin, London, p 313-334

Hiromi J, Nagata T, Kadota S (1988) Respiration of the small planktonic copepod Oithona davisae at different temperatures. Bull Plankton Soc Jpn 35:143-148

Ikeda $T$ (1985) Metabolic rates of epipelagic marine zooplankton as a function of body mass and temperature. Mar Biol 85:1-11

Jahnke RA, Craven DB (1994) The influence of organic matter diagenesis on $\mathrm{CaCO}_{3}$ dissolution at the deep-sea floor. Geochim Cosmochim Acta 58:2799-2809

Kiørboe T, Møhlenberg F, Hamburger K (1985) Bioenergetics of the planktonic copepod Acartia tonsa: relation between feeding, egg production and respiration, and composition of specific dynamic action. Mar Ecol Prog Ser 26:85-97

Klekowski RZ (1977) Microrespirometer for shipboard measurements of metabolic rate of microzooplankton. Pol Arch Hydrobiol 24(Suppl):455-465

Klekowski RZ, Kukina IV, Tumanseva NI (1977) Respiration in the microzooplankton of the equatorial upwellings in the eastern Pacific Ocean. Pol Arch Hydrobiol 24(Suppl): $467-489$

Klyashtorin LB, Yarzombek AA (1973) Energy consumption in active movements of planktonic organisms. Oceanology 13:575-580 (English translation)

Mazzocchi MG, Paffenhöfer GA (1999) Swimming and feeding behavior of the planktonic copepod Clausocalanus furcatus. J Plankton Res 21:1501-1518

Morris MJ, Gust G, Torres JJ (1985) Propulsion efficiency and cost of transport for copepods: a hydromechanical model of crustacean swimming. Mar Biol 86:283-295

Nakamura Y, Turner JT (1997) Predation and respiration by the small cyclopoid copepod Oithona similis: How important is feeding on ciliates and heterotrophic flagellates? J Plankton Res 19:1275-1288

Omori M, Ikeda T (1984) Methods in marine zooplankton ecology. John Wiley \& Sons, New York

Paffenhöfer GA, Köster M (2005) Digestion of diatoms by planktonic copepods and doliolids. Mar Ecol Prog Ser 297: 303-310

Paffenhöfer GA, Mazzocchi MG (2003) Vertical distribution of subtropical epiplanktonic copepods. J Plankton Res 25: 1139-1156

Paffenhöfer GA, Wester BT, Nicholas WD (1984) Zooplankton abundance in relation to state and type of intrusions on the southeastern United States shelf during summer. J Mar Res 42:995-1017

Paffenhöfer GA, Strickler JR, Lewis KD, Richman S (1996) Motion behavior of nauplii and early copepodid stages. J Plankton Res 18:1699-1715

Paffenhöfer GA, Tzeng M, Hristov R, Smith CL, Mazzocchi MG (2003) Abundance and distribution of nanoplankton in the epipelagic subtropical and tropical open Atlantic Ocean. J Plankton Res 25:1535-1549

Paffenhöfer GA, Mazzocchi MG, Tzeng MW (2006) Living on the edge: feeding of subtropical open ocean copepods. PSZN I: Mar Ecol 27:99-108

Pavlova EV (1994) Diel changes in copepod respiration rates. Hydrobiologia 292/293:333-339

Roman MR, Gauzens AL (1996) Copepod grazing in the equatorial Pacific. Limnol Oceanogr 42:623-634

Webber MK, Roff JC (1995) Annual structure of the copepod community and its associated pelagic environment off Discovery Bay, Jamaica. Mar Biol 123:467-479

Winberg GG (1971) Methods for the estimation of production of aquatic animals. Academic Press, New York 